\title{
PENGARUH PEMBELAJARAN BOLA TANGAN TERHADAP KEMAMPUAN INTERAKSI SOSIAL MAHASISWA
}

\author{
Oleh: Bambang Hermansah \\ (Dosen Universitas PGRI Palembang) \\ Email : bambang.hermansah@gmail.com
}

\begin{abstract}
Abstrak
Tujuan penelitian ini adalah untuk mengetahui pengaruh pembelajaran bola tangan terhadap kemampuan interaksi sosial mahasiswa. Metode yang digunakan dalam penelitian ini adalah metode deskriptif ex-postfacto. Hasil penelitian: 1) Pembelajaran bola tangan memberikan pengaruh yang signifikan terhadap kemampuan interaksi sosial mahasiswa yang mengikuti mata kuliah bola tangan di Program Studi Pendidikan Olahraga FKIP Universitas PGRI Palembang. (2) Kemampuan interaksi sosial mahasiswa yang mengikuti mata kuliah bola tangan termasuk dalam kategori baik, individu yaitu sebesar 70,7\% sedangkan kelompok yaitu sebesar 69\%. (3) Hasil observasi juga menunjukkan bahwa kemampuan interaksi sosial mahasiswa yang mengikuti mata kuliah bola tangan termasuk dalam kategori baik, yaitu sebesar 71,82\%. Kesimpulan, pembelajaran bola tangan memberikan pengaruh yang positif dan signifikan terhadap kemampuan interaksi sosial mahasiswa yang mengikuti mata kuliah bola tangan di Program Studi Pendidikan Olahraga FKIP Universitas PGRI Palembang.
\end{abstract}

Kata Kunci : Bola Tangan, Kemampuan Interaksi Sosial.

\section{THE EFFECT OF HAND BALL LEARNING ON STUDENT'S SOCIAL INTERACTION ABILITY}

\begin{abstract}
The purpose of this study was to determine the effect of handball learning on students social interaction skills. The method used in this study is a descriptive expostfacto method. The results of the study: 1) Handball learning has a significant influence on the social interaction ability of students who take part in handball courses in the Sport Education Study Program FKIP Palembang PGRI University. (2) The social interaction ability of students participating in handball courses is in the good category, individuals are $70.7 \%$ while the group is 69\%. (3) The results of the observations also showed that the social interaction ability of students who participated in handball courses was in the good category, which was $71.82 \%$. Conclusion, handball learning has a positive and significant influence on the social interaction ability of students who take part in handball courses in the Sport Education Study Program FKIP Palembang PGRI University.
\end{abstract}

Keywords : Handball, Social Interaction Ability. 
Pengaruh Pembelajaran Bola ....(Bambang Hermansah)

\section{A. PENDAHULUAN}

Olahraga merupakan satu-satunya kegiatan yang mampu menyatukan semua elemen masyarakat tanpa memandang suku, ras maupun agama. Sehingga tak seorang pun di dunia ini yang tidak menyukai kegiatan olahraga. Mulai dari rakyat jelata hingga para pejabat serta pemimpin Negara. Hal ini terjadi karena satu tujuan yaitu menciptakan tubuh yang kuat dan jiwa yang sehat (Hermansah, 2018).

Olahraga bola tangan bersifat indoor. Olahraga bola tangan merupakan suatu permainan yang dimainkan oleh dua regu yang masing-masing terdiri dari tujuh orang. Tiap-tiap regu berusaha memasukkan bola ke dalam gawang regu lawan dan mencegah regu lawan memasukkan bola. Bola boleh dipasing dengan tangan atau dengan mendribelnya beberapa kali ke lantai tanpa menyentuh kedua tangan bersamaan (Hermansah, 2016).

Dalam pembelajaran permainan bola tangan, selain aspek kognitif dan psikomotor, siswa juga belajar mengenai aspek afektif, yaitu hal-hal yang berkaitan dengan perilaku dan sikap. Dari segi afektif ini banyak tujuan dan manfaat yang diharapkan dapat tercapai oleh mahasiswa dalam mengikuti pembelajaran bola tangan, di antaranya sikap sportif, memiliki rasa tanggung jawab, adanya keinginan bekerja sama, cepat mengambil keputusan, menghargai lawan bermain dan lain sebagainya.

Di dalam pembelajaran olahraga, sering ditemui permasalahan dalam interaksi sosial mahasiswa yang tidak sesuai dengan apa yang diharapkan seperti berkata-kata kasar, kurang sopan kepada teman, tidak mentaati perintah dosen, individualis, saling berselisih paham antar teman. Sebagai makhluk sosial, dalam hidupnya manusia pasti membutuhkan bantuan orang lain. Adanya kebutuhan akan bantuan ini merupakan awal terbentuknya interaksi sosial dengan orang lain. Interaksi sosial merupakan suatu hubungan antara individu satu dengan individu lainnya di mana individu yang satu dapat mempengaruhi individu yang lainnya sehingga terdapat hubungan yang saling timbal balik (Walgito, 2000:65). Sama halnya menurut Maryati dan Suryawati (2003:22) yang menyatakan bahwa, interaksi sosial adalah kontak atau hubungan timbal balik atau interstimulasi dan respons antar individu, antar kelompok atau antar individu dan kelompok.

Padahal dalam olahraga bola tangan yang merupakan olahraga permainan dan melibatkan orang lain, yang akan terlaksana jika di dalamnya terdapat hal-hal yang 
menjadi kesepakatan bersama, baik yang berkaitan dengan peraturan, maupun yang berkaitan dengan interaksi sosial seperti kerjasama, saling mempercayai sesama teman dan saling menghargai. Interaksi sosial tercipta dengan baik, maka proses permainan bola tangan berjalan dengan baik pula, terutama hubungan sosial mahasiswa dengan sesamanya atau orang-orang yang ada di dalam kampus.

Dini dalam Syaodih (2005:114) menjelaskan bahwa ada 8 faktor yang mempengaruhi kemampuan interaksi sosial anak. Faktor pertama adalah adanya kesempatan untuk bergaul dengan orang-orang di sekitarnya dari berbagai usia dan latar belakang. Semakin banyak kesempatan yang diberikan kepada anak untuk bergaul dengan orang-orang yang ada dilingkuannya dengan latar belakang dan usia yang berbeda-beda akan dapat mengembangkan kemampuan sosialnya.

Faktor kedua adalah banyak dan bervariasinya pengalaman dalam bergaul dengan orang-orang di lingkungan. Semakin banyak dan bervariasi pengalaman dalam bergaul dengan orang-orang dilingkungannya, maka akan semakin banyak pula hal-hal yang dipelajarinya untuk menjadi bekal dalam meningkatkan ketrampilan sosialnya. Faktor ketiga adalah adanya minat dan motivasi untuk bergaul. Lingkungan yang mendukung dan menyenangkan akan membuat minat dan motivasinya bergaul semakin berkembang. Faktor keempat yang mempengaruhi interaksi sosial anak adalah banyaknya pengalaman yang menyenangkan yang diperoleh melalui pergaulan dan aktivitas sosial. Semakin banyak pengalaman yang menyenangkan yang diperoleh melalui pergaulan dan aktivitas sosialnya, maka keinginan untuk bergaul semakin berkembang.

Faktor kelima adalah adanya bimbingan dan pengajaran dari orang lain yang biasanya menjadi "model" bagi anak. Bimbingan dan pengajaran dalam bergaul hendaknya dilakukan oleh seseorang yang dapat dijadikan model atau contoh yang baik dalam pergaulan bagi anak. Faktor keenam yaitu adanya bimbingan dan pengajaran yang secara sengaja diberikan oleh orang yang dijadikan "model" bergaul yang baik bagi anak. Walaupun kemampuan sosialisasi ini dapat pula berkembang melalui pengalaman bergaul atau dengan meniru perilaku orang lain dalam bergaul, tetapi akan lebih efektif bila ada bimbingan dan pengajaran yang secara sengaja diberikan oleh orang yang dapat dijadikan model atau contoh bergaul yang baik untuk anak. 
Faktor selanjutnya yang berpengaruh terhadap kemampuan interaksi sosial anak adalah adanya kemampuan berkomunikasi yang baik yang dimiliki anak. Anak dituntuk untuk memiliki kemampuan berkomunikasi yang baik dengan orang lain agar dapat mengembangkan kemampuan sosialnya. Kemampuan berkomunikasi ini merupakan inti dari sosialisasi atau interkasi sosial.

Faktor terakhir yang juga dapat mempengaruhi kemampuan interaksi soisal anak adalah adanya kemampuan berkomunikasi yang dapat membicarakan topik yang dimengerti dan menarik baagi orang lain yang menjadi lawan bicara. Ketika berkomunikasi dengan orang lain, anak tidak hanya dituntut untuk berkomunikasi dengan kata-kata yang dapat dipahami, tetapi juga dapat membicarakan topik yang dapat dimengerti dan menarik untuk orang lain yang menjadi lawan bicaranya.

\section{B. METODOLOGI PENELITIAN}

Metode penelitian adalah cara yang digunakan oleh peneliti dalam mengumpulkan data penelitiannya (Arikunto, 2013:203). Berdasarkan pendapat tersebut, maka dalam penelitian ini metode yang akan digunakan adalah metode deskriptif (ex-postfacto). Metode ini digunakan atas dasar pertimbangan bahwa sifat penelitian ini adalah meneliti tentang variabel yang kejadiannya sudah terjadi sebelum penelitian dilaksanakan. Penelitian Ex-postfacto adalah penyelidikan secara empiris yang sistematik, dimana peneliti tidak mempu-nyai kontrol langsung terhadap variabelvariabel bebas (independent variables) karena manifestasi fenomena telah terjadi atau karena fenomena sukar dimanipulasikan (Nazir, 2005:73).

Menurut Sugiyono, (2010:117), populasi adalah yang terdiri generalisasi atas objek/subjek yang mempunyai kualitas dan karakteristik tertentu yang diciptakan oleh peneliti untuk dipelajari dan ditarik kesimpulannya. Populasi dalam penelitian ini adalah mahasiswa yang mengikuti mata kuliah bola tangan di Program Studi Pendidikan Olahraga FKIP Universitas PGRI Palembang, sedangkan teknik sampling yang digunakan yaitu purposive sampling. Sampel penelitian ini adalah mahasiswa semester 4F Pendidikan Olahraga FKIP Universitas PGRI Palembang.

Teknik pengumpulan data yang digunakan dalam penelitian ini adalah kuesioner dan observasi. Kuesioner digunakan untuk mengungkap data pribadi mahasiswa tentang perilaku-perilaku atau sikap sosial mahasiswa di kampus, sedangkan observasi 
dilakukan untuk menambah dan mendukung data hasil dari pengisian kuesioner. Analisis data yang diperoleh dengan cara menghitung nilai rata-rata dari setip butir pertanyaan atau pernyataan pada kuesioner kemudian dilakukan presentase untuk menarik hasil dan kesimpulan.

\section{HASIL DAN PEMBAHASAN}

Berdasarkan hasil pengolahan data, maka hasil penelitian ini dapat dilihat pada tabel berikut:

Tabel 1. Hasil Penelitian Kemampuan Interaksi Sosial Mahasiswa dalam Pembelajaran Olahraga

\begin{tabular}{|c|c|c|c|}
\hline Variabel & Indikator & \% & Kategori \\
\hline $\begin{array}{c}\text { Interaksi sosial } \\
\text { mahasiswa dalam }\end{array}$ & Interaksi Verbal & $74 \%$ & Baik \\
\cline { 2 - 4 } $\begin{array}{c}\text { Pembelajaran Bola } \\
\text { Tangan secara } \\
\text { Individu }\end{array}$ & Interaksi Fisik & $68 \%$ & Baik \\
\cline { 2 - 4 } & Interaksi Emosional & $70 \%$ & Baik \\
\hline $\begin{array}{c}\text { Interaksi sosial } \\
\text { mahasiswa dalam } \\
\text { Pembelajaran Bola } \\
\text { Tangan secara } \\
\text { Kelompok }\end{array}$ & Interaksi Verbal & $71 \%$ & Baik \\
\cline { 2 - 4 } & Interaksi Fisik & $67 \%$ & Baik \\
\cline { 2 - 4 } & Interaksi Emosional & $69 \%$ & Baik \\
\hline
\end{tabular}

Tabel 1 menunjukkan hasil penelitian, interaksi sosial yang dilakukan mahasiswa dalam pembelajaran bola tangan terjadi terhadap individu dan kelompok. Masingmasing interaksi sosial terhadap individu dan kelompok, mahasiswa dalam pembelajaran bola tangan melakukan tiga bentuk interaksi sosial yaitu interaksi verbal, interaksi fisik dan interaksi emosional.

Interaksi sosial yang dilakukan mahasiswa dalam pembelajaran bola tangan terhadap individu dalam bentuk interaksi verbal dilakukan dengan baik dengan persentase $74 \%$. Interaksi fisik yang dilakukan mahasiswa berprestasi terhadap individu juga tergolong dalam kategori baik dengan persentase $68 \%$, sedangkan interaksi emosional juga dilakukan dengan baik dengan persentase 70\%. Secara keseluruhan interaksi sosial yang dilakukan mahasiswa dalam pembelajaran bola tangan terhadap individu pada kategori baik dengan persentase $70,7 \%$. 
Pengaruh Pembelajaran Bola ....(Bambang Hermansah)

Interaksi terhadap kelompok yang dilakukan mahasiswa dalam pembelajaran bola tangan terhadap kelompok juga dalam kategori baik dengan persentase 69\%. Untuk interaksi verbal yang dilakukan siswa berprestasi dalam belajar terhadap kelompok mencapai persentase $71 \%$ dengan kategori baik. Sedangkan interaksi fisik dilakukan dengan persentase $67 \%$ sehingga digolongkan dalam kategori baik. Interaksi emosional dilakukan mahasiswa dalam pembelajaran bola tangan dengan persentase $69 \%$ terhadap kelompok dan juga dikategorikan baik.

\section{Pembahasan}

\section{Interaksi Sosial Mahasiswa dalam Pembelajaran Bola Tangan terhadap Individu maupun Kelompok}

Pada hasil penelitian ini, interaksi sosial yang dilakukan mahasiswa dalam pembelajaran bola tangan terhadap individu dan kelompok, dibagi dalam tiga bentuk yaitu: interaksi verbal, interaksi fisik dan interaksi emosional.

\section{Interaksi Verbal}

Rata-rata interaksi verbal yang dilakukan mahasiswa dalam pembelajaran bola tangan dengan individu tergolong baik dengan persentase $74 \%$ dan kelompok dengan persentase $71 \%$. Meskipun demikian, ada satu item pernyataan yang dilakukan dengan sangat baik yaitu mereka mengucapkan hebat/memuji kepada teman satu tim dengan persentase mencapai $82 \%$. Sebagai mahasiswa, tingkah laku yang bermoral tersebut merupakan sikap yang menjadi cerminan manusia intelektual. Perilaku tersebut dapat menjadi contoh interaksi sosial yang baik dalam kegiatan olahraga.

\section{Interaksi Fisik}

Rata-rata interaksi fisik yang dilakukan mahasiswa dalam pembelajaran bola tangan dengan individu tergolong baik dengan persentase $68 \%$ dan kelompok dengan persentase $67 \%$. Meskipun demikian, ada satu item pernyataan yang dilakukan dengan sangat baik yaitu mereka melakukan tos kepada teman satu tim ketika berhasil memasukkan bola, dengan persentase mencapai $78 \%$. Sebagai mahasiswa, tingkah laku yang bermoral tersebut merupakan sikap yang menjadi acuan kepribadian manusia intelektual. Perilaku tersebut dapat menjadi contoh interaksi sosial yang baik dalam kegiatan olahraga. 


\section{Interaksi Emosional}

Rata-rata interaksi emosional yang dilakukan mahasiswa dalam pembelajaran bola tangan dengan individu tergolong baik dengan persentase $70 \%$ dan kelompok dengan persentase 69\%. Meskipun demikian, ada satu item pernyataan yang perlu diperbaiki yaitu senang melihat teman tidak mendapat operan bola dan dendam kepada sesama tim yang mencetak skor. Sebagai mahasiswa, manusia intelektual sudah selayaknya membina hubungan sosial yang baik, terutama teman sebayanya.

Dari hasil pengolahan data, kemampuan interaksi sosial mahasiswa yang mengikuti mata kuliah bola tangan di Program Studi Pendidikan Olahraga FKIP Universitas PGRI Palembang termasuk dalam kategori baik, individu yaitu sebesar 70,7\% sedangkan kelompok yaitu sebesar 69\%. Observasi dilakukan oleh peneliti dengan tujuan untuk memperoleh data tambahan yang bisa mendukung data yang sudah dihasilkan dengan menggunakan angket. Observasi yang dilakukan yaitu dengan cara mengamati semua interaksi mahasiswa selama perkuliahan bola tangan selama 16 kali pengamatan. Data hasil observasi memperlihatkan bahwa interaksi sosial mahasiswa yang mengikuti mata kuliah bola tangan di Program Studi Pendidikan Olahraga FKIP Universitas PGRI Palembang termasuk dalam kategori baik, yaitu sebesar $71,82 \%$.

\section{SIMPULAN}

Berdasarkan hasil penelitian dan analisis data, maka dapat disimpulkan bahwa pembelajaran bola tangan memberikan pengaruh yang positif dan signifikan terhadap kemampuan interaksi sosial mahasiswa yang mengikuti mata kuliah bola tangan di Program Studi Pendidikan Olahraga FKIP Universitas PGRI Palembang. Hal ini terlihat dari hasil angket kemampuan interaksi sosial termasuk dalam kategori baik, individu yaitu sebesar 70,7\% sedangkan kelompok yaitu sebesar 69\%, serta didukung hasil observasi juga menunjukkan bahwa kemampuan interaksi sosial mahasiswa yang mengikuti mata kuliah bola tangan termasuk dalam kategori baik, yaitu sebesar 71,82\% . 
Pengaruh Pembelajaran Bola ....(Bambang Hermansah)

\section{DAFTAR PUSTAKA}

Arikunto, S. (2013). Prosedur Penelitian Suatu Pendekatan Praktek. Jakarta: Rineka Cipta.

Hermansah, B. (2016). Pengaruh Latihan Bola Digantung terhadap Hasil Shooting pada Siswa Ekstrakurikuler Bola Tangan Kelas VIII SMP N 5 Indralaya Utara. Prosiding Dosen Universitas PGRI Palembang Edisi 19. Jurnal Dosen Universitas PGRI Palembang.

Hermansah, B. (2018). Modifikasi Permainan Bola Tangan terhadap Hasil Belajar Passing dalam Pembelajaran Bola Tangan Mahasiswa. Wahana Didaktika: Jurnal Ilmu Kependidikan (Online). Volume 16 No. 1 Januari 2018 : 35-41. FKIP Universitas PGRI Palembang.

Maryati, \& Suryawati. (2003). Sosiologi 1. Jakarta: Erlangga.

Nazir, M. (2005). Metode Penelitian. Bogor: Ghalia Indonesia.

Syaodih, N. (2005). Landasan Psikologi Proses Pendidikan. Bandung: PT Rosda Karya.

Sugiyono. (2010). Statistik untuk penelitian. Bandung: Alfabeta.

Walgito, Bimo. (2000). Pengantar Psikologi Umum. Yogyakarta: Penerbit Andi. 